\title{
AN ANALYSIS OF ADMISSIONS TO THE PAEDIATRIC DIVISION, MULAGO HOSPITAL IN 1959
}

\author{
BY
}

\author{
LATIMER K. MUSOKE \\ From the Paediatric Division, Mulago Hospital, Kampala, Uganda
}

(RECEIVED FOR PUBLICATION SEPTEMBER 1, 1960)

The last review of admissions to the Children's Ward at Mulago Hospital was for the year 1950-51 by Davies (1954) and, as in all rapidly developing countries the pattern of childhood disease seemed to be varying considerably in response to numerous ecological changes, it was felt that a further more recent study of admissions would be valuable.

\section{Ecological Background}

During the past decade, there has been a large influx of population into Kampala and the adjacent Mengo District of Buganda, and, in addition, people are becoming more and more hospital conscious. Both changes have considerably increased the number of attendances at hospital, thereby creating special problems in looking after an increasing number of patients without an expanding bed space.

An index of the size of the problem is suggested by the fact that, while Uganda's total population is six and a half millions (1960 census), $44 \%$ of these are children. Kampala and Mengo District have shown the greatest increase in population of all parts of Uganda.

The majority of our patients are the Baganda living in rural areas. The parents are peasant farmers, and the cultivation is done by the husband and wife or wives, assisted by labourers for those who can afford to engage them, using a hoe as the only implement for cultivation. There are no villages, but scattered homes; the way of life and the type of houses are changing rapidly. The demand for this change has focused the energies of most people on growing cash crops. Those who can read and write and speak some English drift to the towns to seek jobs in the expanding commercial town of Kampala.

The life of the mothers of most of our patients is very arduous. She has the responsibility of growing food for the family, assisting the husband in cultivating fields of cash crops, providing water and firewood for the family and looking after her own four to eight children. Means of transport are difficult, although getting easier in most parts of the country. It is with these problems that the mother has to forsake her home and other children to bring her sick infant to hospital. This is reflected in the late arrival of many of the cases admitted and the high mortality soon after admission.

The life of the educated and wealthier people is easier. They have quick means of transport. Mothers can attend child welfare clinics around Kampala, can afford to add milk to their children's diet and take their children sooner for medical advice.

The immigrant tribes, designated as 'others' in this paper, include the Luo, Toro, Kiga, Nkole, Nubians, Lugbara, Nyoro, Alur, Lango, Atesot and Acholi, some of whom live in scattered housing estates around the town, and the overcrowded built-up slum areas that are found around big towns all over East Africa. They live the double life of working in towns until they have saved enough money to go home and stay at home for months before returning to work. They may or may not have their families with them. Their social problems are similar to those of other rapidly expanding towns in East Africa.

The other big single group of immigrant tribes is that of people from Ruanda-Urundi, who come to work on large non-African plantations or get employed in rural areas on African farms. They face the strain of the journey, meet the problem of shortage of food in a subsistence agricultural community, work and save money to take home, and are exposed to new and different kinds of tropical parasites, as, for example, the severe manifestations of clinical malaria seen in those arriving in Kampala from the mountainous nonmalarial parts of Ruanda-Urundi. A higher incidence of kwashiorkor is found in children of this group.

The Paediatric Division is part of Mulago Hospital, the teaching hospital of the University College 


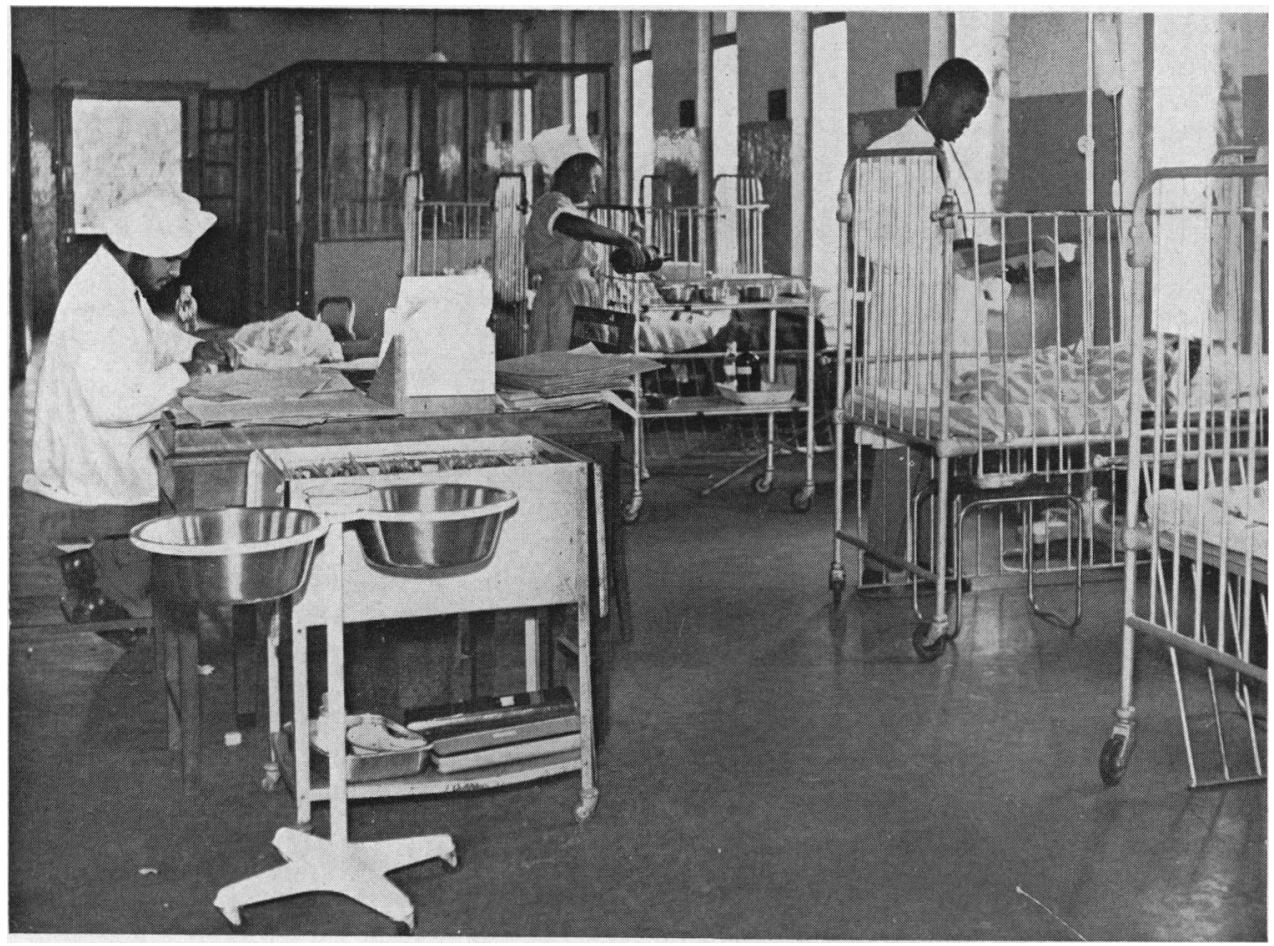

of East Africa. In-patient facilities consist of 50 beds with daily admission of cases from the children's out-patients and cases seen after hours in the casualty department. ${ }^{*}$ There is no 24-hour laboratory service. An attempt is made to carry out certain simple routine examinations on all admissions and, in fact, they are done in about $85 \%$ of cases. These include blood slides for malarial parasites, wet film preparations for sickling, haemoglobin estimations and stool examinations, which are carried out in a ward side room by a technician whose services are available from 8 a.m. to 4 p.m. on weekdays. Special blood investigations can be sent to the hospital haematologist and the biochemical laboratory. Tests are done by the Government biochemists, working in a laboratory a mile away from the hospital. It is under such circumstances of daily admissions, without laboratory assistance after 4 p.m., in an overcrowded ward (see Fig.), that the care of children, $81 \%$ of whom are below 3 years of age, has to be accomplished.

* The number of children attending the hospital, however, is so large that the present beds of the Paediatric Division are sufficient in number to cope only with the children up to the age of about 6 years. Older children are accommodated in adult wards and are not included in this review. Also omitted are a number of children admitted to the T.B. ward, ophthalmic and to surgical wards for specialist's care. This situation should be partly rectified when the New Mulago Hospital is opened.

\section{Admissions}

This analysis covers admissions to the Paediatric Division during the year 1959. The total number in the ward register was 1,380 .

The overall grouping of causes of admission has been classified according to their order of frequency and their mortality (Table 1).

Diseases have been classified as separate entries according to the main diagnosis on admission; therefore, each case appears once in the Table, although a combination of diseases in the same patient was a very common finding.

The turnover of patients in the ward is very high. Many patients die soon after admission, before any investigations are done. Autopsies are very often refused. It is in the light of these difficulties that the diagnoses have to be interpreted.

The preponderance of males over females is observed and cannot be explained as the census figures for this country give the ratio between males and females as about equal.

Gastro-intestinal Diseases. Out of 231 cases admitted in this group, 200 were suffering from gastro-enteritis, $38(18 \%)$ of whom died. Other conditions were: six enteric fever (all recovered); 10 intestinal obstruction (five intussusception, three 
TABLE 1

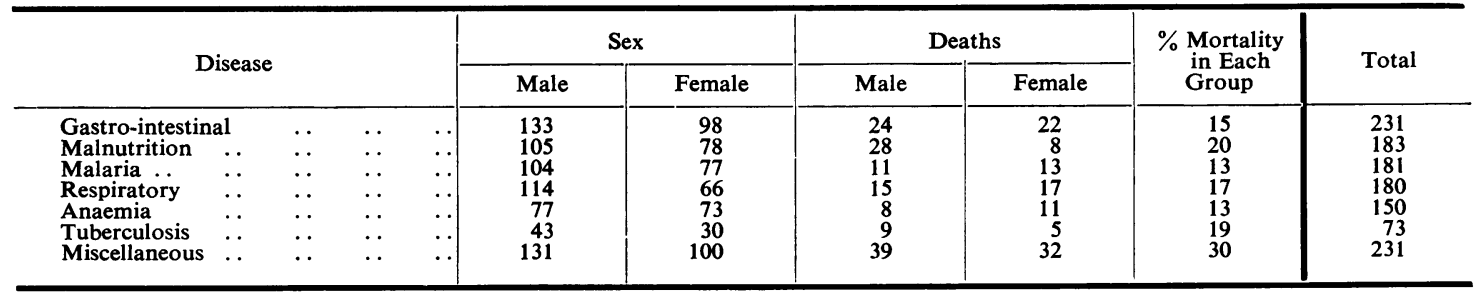

ileus from infection, one impacted faeces, one with no cause found after laparotomy), with four deaths; 12 liver disease (classified as: six infective hepatitis, four cirrhosis of the liver and two undiagnosed hepatic disease); three cases of liver disease died. All the helminthic diseases have not been included in this group as they would rarely be causes for admission, although three cases of clinical disease due to ascariasis were admitted, with one death from peritonitis, without perforation, being found at autopsy. Hookworm disease, a severe and common malady, has been considered separately.

Malnutrition. In this group, kwashiorkor, with 136 cases, makes up $10 \%$ of the admissions, with the highest mortality of $20 \%$. The marasmus group is made up for the most part of cases of failure to thrive as a result of inability to manage artificial feeding, combined with intercurrent infections. There were 47 cases, approximately $4 \%$ of admissions, with six deaths.

Malaria. All cases with positive blood slides for malaria are not included here; it is only the cases where clinical malaria was the main reason for admission that are considered. In 26 cases (out of the total of 181), the diagnosis was only clinical without a positive blood slide for malaria.

Respiratory Diseases. Out of 180 cases, pneumonia was diagnosed in 113 children, with $23(20 \%)$ deaths. Twenty-nine were suffering from laryngotracheo-bronchitis, with seven $(24 \%)$ deaths; eight with bronchitis (one death) and four with pertussis (one death). Other conditions seen were: acute upper respiratory infections 23 , bronchial asthma two and pulmonary collapse one. All recovered.
Anaemia. Of the total admissions, 144 cases $(10.4 \%)$ were classified as anaemia; 61 cases were admitted due to hookworm anaemia, with five $(8 \cdot 3 \%)$ fatal results. The diagnosis of sickle cell anaemia, made in 66 children, was based on positive sickling, dactylitis, characteristic radiological bony changes and presence of haemoglobin $S$ on electrophoresis (the latter being necessary as $17 \%$ of healthy Baganda have the sickle cell trait). In 17 cases, the anaemia was of uncertain origin.

Tuberculosis. Of the total admissions $73(5 \cdot 3 \%)$ were suffering from tuberculosis, i.e. pulmonary 60 , with a mortality of $18 \%$; bone four, with one fatal case; meningitis five, with two deaths, and glandular four, all recovering.

Miscellaneous. Other causes for admission, that are not mentioned above, will be analysed later.

\section{Age and Sex}

Some of the mothers can give a reliable age and sometimes the exact date of birth of their children in the first two years. In the case of illiterate parents, who can only recall the age from memory, it is considered that the accuracy is fair for infants, but in the older children ages can only be roughly expressed.

The grouping of the ages in years for all admissions is shown in Table 2.

It can be seen that the childhood morbidity is greatest in the first two years of life and steadily decreases thereafter. This is also shown in Table 3, which gives the incidence of the various major disease groups at different ages.

TABLE 2

\begin{tabular}{|c|c|c|c|c|c|c|c|c|c|c|}
\hline \multirow{2}{*}{\multicolumn{3}{|c|}{ Sex }} & \multicolumn{8}{|c|}{ Age Groups (years) } \\
\hline & & & \multirow{2}{*}{$\begin{array}{l}0-1 \\
308 \\
230\end{array}$} & \multirow{2}{*}{$\begin{array}{l}1-2 \\
214 \\
146\end{array}$} & \multirow{2}{*}{$\begin{array}{r}2-3 \\
105 \\
77\end{array}$} & \multirow{2}{*}{$\begin{array}{c}3-4 \\
49 \\
30\end{array}$} & \multirow{2}{*}{$\begin{array}{r}4-5 \\
48 \\
27\end{array}$} & \multirow{2}{*}{$\begin{array}{c}5-6 \\
20 \\
17\end{array}$} & \multirow{2}{*}{$\begin{array}{l}6+ \\
23 \\
30\end{array}$} & \multirow{2}{*}{$\begin{array}{c}\text { Not Recorded } \\
15\end{array}$} \\
\hline $\begin{array}{l}\text { Male .. } \\
\text { Female }\end{array}$ & $\cdots$ & $\therefore$ & & & & & & & & \\
\hline \multicolumn{3}{|c|}{ Total } & 538 & 360 & 182 & 79 & 75 & 37 & 53 & 24 \\
\hline
\end{tabular}


TABLE 3

INCIDENCE OF VARIOUS MAJOR DISEASE GROUPS AT DIFFERENT AGES

\begin{tabular}{|c|c|c|c|c|c|c|c|c|c|}
\hline \multirow{2}{*}{\multicolumn{2}{|c|}{ Disease }} & \multicolumn{8}{|c|}{ Age } \\
\hline & & $6 \mathrm{mths}$ & $6 \mathrm{mths}-1 \mathrm{yr}$ & 1-2 years & 2-3 years & $3-4$ years & 4-5 years & 5-6 years & $6+$ years \\
\hline $\begin{array}{l}\text { Gastroenteritis } \\
\text { Kwashiorkor } \\
\text { Marasmus .. . . } \\
\text { Malaria } \\
\text { Respiratory diseases } \\
\text { Hookworm anaemia } \\
\text { Tuberculosis }\end{array}$ & \begin{tabular}{l|}
$\cdots$ \\
$\cdots$ \\
$\cdots$ \\
$\cdots$ \\
$\cdots$ \\
$\cdots$
\end{tabular} & $\begin{array}{r}18 \\
20 \\
25 \\
46 \\
2 \\
3\end{array}$ & $\begin{array}{r}108 \\
20 \\
11 \\
46 \\
40 \\
6 \\
24\end{array}$ & $\begin{array}{l}50 \\
80 \\
13 \\
67 \\
52 \\
14 \\
22\end{array}$ & $\begin{array}{r}12 \\
27 \\
3 \\
26 \\
25 \\
23 \\
7\end{array}$ & $\begin{array}{l}8 \\
5 \\
8 \\
3 \\
7 \\
4\end{array}$ & $\begin{array}{l}1 \\
3 \\
7 \\
5 \\
5 \\
7\end{array}$ & $\begin{array}{l}2 \\
1 \\
2 \\
6 \\
5 \\
4\end{array}$ & $\begin{array}{r}2 \\
1 \\
- \\
1 \\
1 \\
2\end{array}$ \\
\hline
\end{tabular}

Neonatal Disease. Eighty-three newborn babies were admitted to the ward, with the diseases shown in Table 4.

TABLE 4

83 NEONATAL ADMISSIONS TO GENERAL PAEDIATRIC WARD

\begin{tabular}{|c|c|c|}
\hline Disease & Number & Deaths \\
\hline 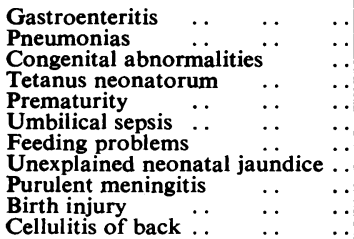 & $\begin{array}{r}11 \\
11 \\
11 \\
10 \\
10 \\
10 \\
7 \\
6 \\
3 \\
3 \\
1\end{array}$ & $\begin{array}{r}6 \\
5 \\
3 \\
10 \\
5 \\
4 \\
1 \\
2 \\
3 \\
2 \\
-\end{array}$ \\
\hline
\end{tabular}

This does not, in fact, necessarily represent the local pattern of neonatal disease as sick newborn babies are also nursed in a side ward adjacent to the maternity ward; while, owing to the very short stay in hospital after delivery (necessitated by the extremely heavy bed pressure in the Maternity Division), it is likely that many neonatal diseases occur after discharge, and the babies may not be brought back for therapy.

\section{Tribal Distribution}

The pattern of life for people living in towns is becoming more uniform and the record of a patient's tribe, for those in the same income group, is often more likely to indicate his geographical origin rather than a different way of living. The only tribal distinction which is significant for the people around Kampala is to divide them into those families who produce practically all their vegetable food from their gardens and those who have to buy it from the market. It is generally accepted that the Ruanda-Urundi and other tribes who form the majority of the labourer class in Buganda are at an economic and nutritional disadvantage, and obtain most of their food from markets.

There are two rainy seasons each year and it is only in exceptional circumstances, when the rains fail, that actual shortage of food is experienced in this part of the country. It seems, therefore, that the factors leading to severe malnutrition are not mainly attributable to shortage of food, but to the low protein content of the staple food used in this country and to lack of knowledge of nutritional needs.

The tribal distribution of the admissions was as followis:

\begin{tabular}{|c|c|c|c|}
\hline Tribes & Male & Female & Total \\
\hline $\begin{array}{lll}\text { Ganda } & \ldots & \ldots \\
\text { Ruanda-Urundi } & \ldots \\
\text { Others } & \ldots & \ldots\end{array}$ & $\begin{array}{l}455 \\
120 \\
200\end{array}$ & $\begin{array}{r}378 \\
80 \\
100\end{array}$ & $\begin{array}{l}833 \\
200 \\
300\end{array}$ \\
\hline
\end{tabular}

The admissions of major disease groups analysed according to tribe are shown in Table 5.

TABLE 5

ADMISSIONS ACCORDING TO THE MAJOR DISEASES, ANALYSED BY TRIBE

\begin{tabular}{|c|c|c|c|c|}
\hline & & Ganda & $\underset{\text { Urundi }}{\text { Ruanda- }}$ & Others \\
\hline $\begin{array}{ll}\text { Gastroenteritis } & \ldots \\
\text { Kwashiorkor } & \ldots \\
\text { Marasmus } & \ldots \\
\text { Malaria . } & \ldots \\
\text { Respiratory diseases } \\
\text { Hookworm anaemia } \\
\text { Tuberculosis }\end{array}$ & $\begin{array}{l}\cdots \\
\cdots \\
\cdots \\
\cdots \\
\cdots \\
\cdots\end{array}$ & $\begin{array}{r}134 \\
70 \\
19 \\
133 \\
117 \\
22 \\
38\end{array}$ & $\begin{array}{l}15 \\
40 \\
16 \\
13 \\
22 \\
32 \\
18\end{array}$ & $\begin{array}{r}51 \\
21 \\
10 \\
35 \\
40 \\
7 \\
17\end{array}$ \\
\hline
\end{tabular}

\section{Seasonal Variation}

Analysis of total admissions on a monthly basis showed no significant seasonal variation (Table 6.)

TABLE 6

\begin{tabular}{|c|c|c|c|c|c|c|c|c|c|c|c|c|c|}
\hline $\begin{array}{l}\text { Month } \\
\text { Cases }\end{array}$ & $\therefore$ & $\begin{array}{l}\text { Jan } \\
102\end{array}$ & $\begin{array}{l}\text { Feb } \\
101\end{array}$ & $\underset{110}{\text { Mar }}$ & $\begin{array}{l}\text { Apr } \\
108\end{array}$ & $\begin{array}{c}\text { May } \\
114\end{array}$ & $\begin{array}{c}\text { June } \\
128\end{array}$ & $\begin{array}{l}\text { July } \\
121\end{array}$ & $\begin{array}{l}\text { Aug } \\
100\end{array}$ & $\begin{array}{l}\text { Sept } \\
104\end{array}$ & $\begin{array}{l}\text { Oct } \\
118\end{array}$ & $\begin{array}{l}\text { Nov } \\
121\end{array}$ & $\begin{array}{l}\text { Dec } \\
118\end{array}$ \\
\hline
\end{tabular}


TABLE 7

\begin{tabular}{|c|c|c|c|c|c|c|c|c|c|c|c|}
\hline & & & & \multicolumn{8}{|c|}{ Age (years) } \\
\hline & & & & $0-1$ & $1-2$ & $2-3$ & $3-4$ & $4-5$ & $5-6$ & 6 & Not Recorded \\
\hline $\begin{array}{l}\text { No. of cases admitted } \\
\text { No. died ... } \\
\% \text { deaths } / \text { admissions } \\
\% \text { total deaths } \ldots\end{array}$ & $\begin{array}{l}\cdots \\
\cdots \\
\cdots\end{array}$ & $\begin{array}{l}\cdots \\
\cdots \\
\cdots\end{array}$ & \begin{tabular}{l|}
$\cdots$ \\
$\cdots$ \\
$\cdots$
\end{tabular} & $\begin{array}{r}538 \\
97 \\
18 \\
40\end{array}$ & $\begin{array}{r}360 \\
68 \\
19 \\
28\end{array}$ & $\begin{array}{r}182 \\
22 \\
12 \\
9\end{array}$ & $\begin{array}{r}79 \\
16 \\
20 \\
7\end{array}$ & $\begin{array}{r}75 \\
6 \\
8 \\
2\end{array}$ & $\begin{array}{r}37 \\
6 \\
16 \\
2\end{array}$ & $\begin{array}{r}53 \\
11 \\
21 \\
5\end{array}$ & $\begin{array}{r}24 \\
16 \\
67 \\
6\end{array}$ \\
\hline
\end{tabular}

This failure to demonstrate seasonal variation in the admissions does not exclude its existence, but rather suggests that the demand for beds is all the time so much above the available bed space. As no more cases are allowed to the ward than the number of beds admit, the variation in the number of cases requiring admission has to be considerable to cause variation in the figure of admissions each month.

\section{Deaths}

The overall distribution of deaths according to age is given in Table 7.

As might be expected, the highest wastage of life is in the first year of life.

In the group where age was not recorded the mortality rate was $67 \%$, which suggests that many died soon after admission before being fully examined. It is not possible to give the exact time to the hour spent in hospital before death, as the time is not recorded when the patient enters the hospital, when he is seen by a doctor or when he arrives in the ward. It is useful, however, to note that 93 patients died within 24 hours of their admission and 28 within the second 24 hours. Of the deaths, therefore, $50 \%$ occurred within 48 hours of arriving in the hospital.

Autopsies were performed in only $34(14 \%)$ cases. It is obvious that the problem of obtaining consent for autopsies from parents and relatives is great.

\section{Consideration of Main Disease Groups}

(I) Diarrhoea and Vomiting Syndrome (Gastroenteritis). It is significant that a disease which seven years ago was considered to be quite uncommon, now tops the list of admissions. Davies (1954) stated that diarrhoea and vomiting were relatively unimportant causes for admission of children in Mulago Hospital. Welbourn (1955) noted that the cases of diarrhoea and vomiting in her child welfare clinics were relatively mild and did not require hospital treatment.

The present analysis shows that the diarrhoea and vomiting syndrome has become one of the major problems in the ward. Luder (1956) classified his cases into groups according to the cellular exudate in the stools, severity of diarrhoea and vomiting, and the degree of dehydration. It has not been possible to do the same in the present series, as cases did not form part of a special investigation.

The duration of stay in hospital averaged $4 \cdot 4$ days, and details are given in Table 8.

The age distribution of children with gastroenteritis is given in Table 9.

It can be seen that the age incidence has its peak under 2 years of age and becomes rarer thereafter, thus behaving like diarrhoea and vomiting in the temperate zones (Luder, 1956).

In the cases with prolonged and severe diarrhoea, potassium deficiency was suspected in a number of cases. This was observed clinically by ileus, hypotonia, cardiac irregularity and localized woody oedema. Lack of adequate biochemical laboratory facilities prevented the estimation of electrolytes in the blood in most cases. Without a 24-hour laboratory service results are not likely to be in time to assist in the immediate treatment of the patient.

TABLE 8

\begin{tabular}{|c|c|c|c|c|c|c|c|c|c|c|c|c|c|c|c|}
\hline $\begin{array}{ll}\text { Days } & \ldots \\
\text { Cases } & \ldots\end{array}$ & $\begin{array}{l}. . \\
. .\end{array}$ & $\begin{array}{r}1 \\
34\end{array}$ & 31 & $\begin{array}{r}3 \\
33\end{array}$ & $\begin{array}{r}4 \\
33\end{array}$ & $\begin{array}{r}5 \\
19\end{array}$ & $\begin{array}{r}6 \\
10\end{array}$ & $\begin{array}{r}7 \\
11\end{array}$ & $\begin{array}{l}8 \\
4\end{array}$ & $\begin{array}{l}9 \\
4\end{array}$ & $\begin{array}{r}10 \\
3\end{array}$ & $\begin{array}{r}11 \\
3\end{array}$ & 12 & $\begin{array}{r}13 \\
4\end{array}$ & $\begin{array}{l}14 \\
10\end{array}$ \\
\hline \multicolumn{16}{|c|}{ TABLE 9} \\
\hline Age (years) & .. & .. & $<6 \mathrm{mths}$ & & mths & $1-2$ & & $2-3$ & & $3-4$ & & & $5-6$ & & 6 \\
\hline Cases ... & $\ldots$ & i & 7 & 1 & 119 & 50 & & 12 & & 8 & & & 1 & & 2 \\
\hline Deaths .. & . & 1 & & 25 & & 9 & & 2 & & - & & & 1 & 1 & 1 \\
\hline
\end{tabular}


Similarly, bacteriological investigation was not possible. However, in a series of 100 cases reported previously by Wilson and Luder (1957) pathogens were found in 33 cases (Shigella 25, Salmonella 6, Escherichia coli 3 -one child having a double infection).

TRIBE AND Diet. There is a low incidence in the Ruanda-Urundi group (15 cases) and the highest incidence is in the Baganda (134 cases).

Dietary data showed that only 27 children were exclusively breast fed at the time of illness, while 23 were bottle fed only, 68 were breast fed with supplements of cow's milk and 35 were receiving a solid diet. Adequate details were not available in 45 children.

The interpretation of this tribal distribution and method of infant feeding is probably principally related to the fact that in the Ruanda-Urundi breast feeding is not only more universal and prolonged but, more important, is given unsupplemented. In the Baganda, although many do still breast-feed their babies, early supplementary feeding is increasing and, as feeds are often prepared in an unhygienic way, this predisposes to gastroenteritis.

MALARIA. Blood slides were examined for malaria in $156(78 \%)$ cases of gastroenteritis, only nine were recorded positive for malarial parasites and in only three was a heavy parasitaemia recorded. It appears, therefore, that malarial diarrhoea and vomiting has not contributed much to the large number of cases in this series. Parenteral infection is said to cause in the temperate zones $30 \%$ (Scott, 1953) to $60 \%$ of the cases (Greaves and Welch, 1951, quoted by Luder, 1956). In the present series its status is uncertain, but it was not often considered to be aetiologically significant, although in two cases chronic otitis media was present and in another child, pneumonia was recorded.

AnAemia. Haemoglobin estimations in this type of infection are given in Table 10.

Deaths. Thirty-eight (19\%) patients died, 12 (31\%) dying within 24 hours of admission. In $31 \%$ of the cases, admission was after a seven-day history. Many patients were admitted with a very severe degree of dehydration, not infrequently associated with malnutrition.

(II) Malnutrition. In this series, protein-calorie malnutrition formed $14 \%$ of the total admissions and caused the highest mortality. There have been several recent reviews of the subject (Jelliffe, 1959). Welbourn $(1955,1958)$ has discussed feeding problems, as seen in this country.

In the present series, the following tribal and age distributions were found in kwashiorkor and in marasmus (Table 11).

Whereas in kwashiorkor the highest incidence is between the first and second year of life, in the marasmus group the main incidence is in the first six months of life. The figures here are unreliable as, due to the shortage of bed space, only the severely ill cases were admitted.

\section{ADDED INFECTIONS AND INFESTATIONS}

(i) Malaria. In $82 \%$ of the cases blood slides were examined for malarial parasites; $25 \%$ were recorded positive. Davies (1954) recorded $46 \%$ cases of kwashiorkor complicated by malaria in the Ganda and non-Ganda together.

(ii) Hookworm. In $64 \%$ of the cases stools were

TABLE 10

\begin{tabular}{|c|c|c|c|c|c|c|c|c|c|}
\hline $\begin{array}{l}\mathrm{Hb}(\mathrm{g} . / 100 \mathrm{ml} .) \\
\text { Cases } \ldots\end{array}$ & $\begin{array}{l}\ldots \\
\cdots\end{array}$ & $<{ }_{2}^{4} \cdot 2$ & $\begin{array}{c}4 \cdot 2-5 \cdot 6 \\
3\end{array}$ & $\begin{array}{c}5 \cdot 6-7 \\
12\end{array}$ & $\begin{array}{c}7-8 \cdot 4 \\
18\end{array}$ & $\frac{8 \cdot 4-9}{53} \cdot 8$ & $9 \cdot \frac{8-11}{39} \cdot 2$ & $\begin{array}{c}11 \cdot 2-12 \cdot 6 \\
15\end{array}$ & $\begin{array}{c}12 \cdot 6-14 \\
2\end{array}$ \\
\hline
\end{tabular}

TABLE 11

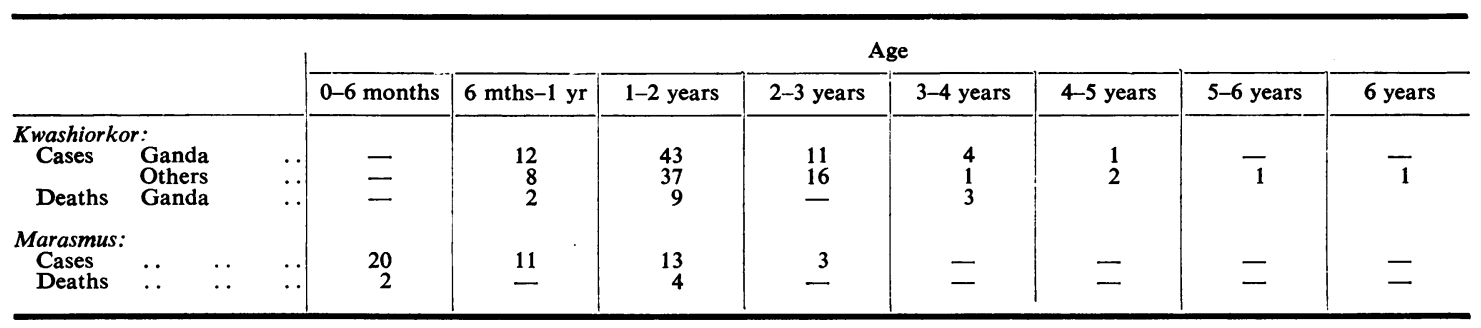


TABLE 12

\begin{tabular}{|c|c|c|c|c|c|c|c|c|c|}
\hline $\mathrm{Hb}(\mathrm{g} . / 100 \mathrm{ml}$ & & $\ldots$ & $<4 \cdot 2$ & $4 \cdot 2-5 \cdot 6$ & $5 \cdot 6-7$ & $7 \cdot 0-8 \cdot 4$ & $8 \cdot 4-9 \cdot 8$ & $9 \cdot 8-11 \cdot 2$ & $11 \cdot 2-12$ \\
\hline $\begin{array}{l}\text { Kwashiorkor } \\
\text { Marasmus }\end{array}$ & 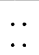 & $\begin{array}{l}\cdots \\
\cdots\end{array}$ & $\begin{array}{r}13 \\
2\end{array}$ & $\begin{array}{r}24 \\
2\end{array}$ & $\begin{array}{r}17 \\
6\end{array}$ & $\begin{array}{r}20 \\
7\end{array}$ & $\begin{array}{l}28 \\
10\end{array}$ & $\begin{array}{r}12 \\
3\end{array}$ & $\begin{array}{l}1 \\
2\end{array}$ \\
\hline
\end{tabular}

examined and $38 \%$ of those examined were recorded as having hookworm ova, but whether it was a light or heavy infection it was impossible to say.

(iii) Ascaris. Only three positives were recorded among the 87 stools examined. These figures do not give the true picture of the diseases complicating kwashiorkor, as investigations were not carried out in every case.

(iv) Respiratory Infections. These include pulmonary tuberculosis and are known to be common in kwashiorkor. Davies (1954) was of the opinion that they were almost part of the disease. They are known to be as common as before; penicillin administration formed part of the routine treatment.

It can be seen that most of the cases were quite anaemic (Table 12). The nature of the anaemia was not investigated specifically and because of the multiple pathology in many of the cases it was usually difficult to be certain of the aetiology. It is known that, apart from the infections and infestations present, deficiency of protein, iron and folic acid can contribute to the anaemia of kwashiorkor. The marasmus group were not as anaemic as the children with kwashiorkor.

Five children required blood transfusions. In these, the stools were positive for hookworm ova in four out of five, so that the anaemia could be at least partially attributed to these helminths.

The dietetic history was not analysed. The diagnosis of mild forms of malnutrition is very difficult in a country where infection and infestation with worms are very common. A fact which parents of a patient cannot understand is how a child can develop malnutrition in spite of eating and satisfying his hunger with starchy foods, such as steamed plantain (matoke). A comparison of the common foods eaten in this country with milk, as regards the protein-calorie ratio, shows that, even if the food eaten can satisfy hunger, it cannot provide the protein required for the growing child. Milk provides 15 to $20 \%$ of the calories from proteins; plantains, yams and sweet potatoes provide 3 to $6 \%$ of the calories from proteins and cassava about $2 \%$. A child requires $14 \%$ of his calories from proteins. It is the understanding of this basic problem which is one of the underlying factors in the causation of malnutrition in this region where children are fed almost exclusively on plantains, sweet potatoes and cassava.
The mortality rate has been high $(20 \%)$, but in a complex disease like malnutrition, which develops slowly, it is not likely that treatment, no matter how effective it may be, will immediately alter the widespread damage done to the vital organs. It is not surprising, therefore, that $25(69 \%)$ of the deaths occurred within 48 hours of admission. Another reason why mortality is high is that, because of the limited bed-space only seriously ill cases of kwashiorkor are admitted.

(III) Malaria. Malaria causes many symptoms in children: convulsions, diarrhoea and vomiting, severe anaemia, jaundice and bronchitis; while repeated attacks cause failure to thrive. The finding of parasites in the blood does not solve the problem, as positive blood slides for malaria are often seen as coincidental findings in other conditions. The differential diagnosis of malaria from virus infections and other obscure fevers is still an immense problem in tropical paediatrics.

Blood slides are routinely examined in the ward or in the out-patients' department from almost every child. The different strains of malaria may be found here but, in the present series, malignant tertian malaria has been almost the only parasite recorded.

The following observations have been made from the records:

\begin{tabular}{|c|c|c|c|c|c|c|c|}
\hline Age Group (yrs) & $0-1$ & $1-2$ & $2-3$ & $3-4$ & $4-5$ & $5-6$ & 6 \\
\hline $\begin{array}{l}\text { Cases... } \\
\text { Deaths }\end{array}$ & $\begin{array}{l}71 \\
11\end{array}$ & $\begin{array}{r}67 \\
5\end{array}$ & 26 & $\begin{array}{l}8 \\
2\end{array}$ & $\begin{array}{l}7 \\
1\end{array}$ & $\underline{2}$ & 二 \\
\hline
\end{tabular}

Eight cases were admitted with malaria in the first three months of life and most of these were Baganda. Davies (1954) noted a highly significant difference between Baganda and non-Ganda in the incidence of malaria in the neonatal period. In the present small series this has not been borne out.

AGE DISTRIBUTION ACCORDING TO TRIBE (UP TO 2 YEARS)

\begin{tabular}{|c|c|c|c|}
\hline Age Group & 6 months & 1 year & $1-2$ years \\
\hline $\begin{array}{l}\text { Ganda } \\
\text { Ruanda-Urundi } \\
\text { Others }\end{array}$ & $\begin{array}{r}17 \\
4 \\
4\end{array}$ & $\begin{array}{r}26 \\
2 \\
14\end{array}$ & $\begin{array}{r}54 \\
5 \\
12\end{array}$ \\
\hline
\end{tabular}


TABLE 13

\begin{tabular}{|c|c|c|c|c|c|c|c|c|c|c|c|c|c|c|}
\hline $\begin{array}{l}\text { Month . . } \\
\text { Admissions }\end{array}$ & $\begin{array}{l}\cdots \\
\cdots\end{array}$ & $\ldots$ & $\underset{8}{\operatorname{Jan}}$ & $\begin{array}{c}\text { Feb } \\
13\end{array}$ & $\underset{20}{\operatorname{Mar}}$ & $\underset{15}{\text { Apr }}$ & $\underset{26}{\text { May }}$ & $\underset{26}{\text { June }}$ & $\begin{array}{c}\text { July } \\
18\end{array}$ & $\underset{11}{\text { Aug }}$ & $\underset{6}{\text { Sept }}$ & $\underset{11}{\text { Oct }}$ & $\begin{array}{c}\text { Nov } \\
8\end{array}$ & $\begin{array}{c}\text { Dec } \\
19\end{array}$ \\
\hline \multicolumn{15}{|c|}{ TABLE 14} \\
\hline \multicolumn{2}{|c|}{$\begin{array}{l}\mathrm{Hb}(\mathrm{g} . / 100 \mathrm{ml} .) \\
\text { Cases } \ldots\end{array}$} & $\begin{array}{l}\cdots \\
\cdots\end{array}$ & \multicolumn{2}{|c|}{$<\underset{25}{4 \cdot 2}$} & $\begin{array}{c}4 \cdot 2-5 \cdot 6 \\
16\end{array}$ & \multicolumn{2}{|r|}{$\begin{array}{c}5 \cdot 6-7 \cdot 0 \\
12\end{array}$} & \multicolumn{2}{|c|}{$\begin{array}{c}7 \cdot 0-8 \cdot 4 \\
19\end{array}$} & \multicolumn{2}{|c|}{$\begin{array}{c}8 \cdot 4-9 \\
27\end{array}$} & $\frac{9 \cdot 8-11 \cdot 2}{21}$ & \multicolumn{2}{|c|}{$11 \cdot 2-12 \cdot 6$} \\
\hline
\end{tabular}

Table 13 shows the number of cases admitted to the ward in each month:

Malarial Anaemia. Haemoglobin estimations were done in most of the cases and the results are shown in Table 14.

Many of the affected children were very anaemic, but responded to malarial drugs and iron. Fifteen $(8 \%)$ cases had to be transfused. One child diagnosed as blackwater fever recovered; eight cases were diagnosed as cerebral malaria and of these two died.

AdDED INfections. Seven cases of malaria also had hookworm infection, two showed ascaris and hookworm and one child had a tapeworm.

(IV) Tuberculosis. The diagnosis of tuberculosis in children is difficult, as sputum is not easily obtained in this young age group. Interpretations of gastric washings, where other acid-fast bacilli may be found, can be misleading, and culture or animal inoculation entails a long delay. In any case, bacteriological facilities are not available at present in sufficient amount to deal with all cases.

The tuberculin test, which is very useful in arriving at a diagnosis in children, often gives results in our patients which are inconsistent. This may be due to many factors but, in the undernourished children with advanced tuberculosis, anergy can develop.

It was by considering the history, clinical examination, the presence of definite or suspicious radiological evidence of tuberculosis, or by deciding to use the therapeutic test that the diagnosis was made in most of the cases.

Seventy-three cases forming approximately 5\% of the total admissions were classified as having tuberculosis. Four were of bone (one death), four with glandular involvement (no deaths), and five had tuberculous meningitis (two deaths). Pulmonary tuberculosis accounted for 60 cases with 11 deaths.

The age distribution of tuberculosis cases was as follows:

\begin{tabular}{ll|l|l|l|l|l|l|l}
\hline $\begin{array}{l}\text { Age (years) } \\
\text { Cases }\end{array}$ &. & $0-1$ & $1-2$ & $2-3$ & $3-4$ & $4-5$ & $5-6$ & 6 \\
\hline
\end{tabular}

HAEMOGLOBIN. This was estimated and the results are given in Table 15.

ADDED INFECTIONS. Blood slides for malaria gave the following results: eight positive, in eight cases it was not done, and the rest were negative.

STools. Twenty were examined and eight showed hookworm ova.

(V) Anaemia. The common causes of anaemia are hookworm, sickle cell disease and malaria. A few cases of unexplained haemolytic anaemia are found. Of cases of anaemia $144(10.4 \%$ of total admissions) can be separated into the following groups: 61 hookworm anaemia (five or $8.3 \%$ deaths), 66 sickle cell anaemia and 17 cases of unspecified anaemia (six or $35 \%$ deaths). (Malaria anaemia is not considered here, but has been dealt with earlier.)

Hookworm Anaemia. The diagnosis of hookworm anaemia is arrived at by exclusion of the other two common causes of anaemia and the finding of occult blood in the stool. The finding of a large number of hookworm ova in the stool is very suggestive, but as a combination hookworm infestation, malaria infection, the sickle cell gene (in either the heterozygous or homozygous states) and malnutrition can occur in the same patient; it is often difficult to make a firm diagnosis.

TABLE 15

\begin{tabular}{|c|c|c|c|c|c|c|c|c|}
\hline $\begin{array}{l}\mathrm{Hb}(\mathrm{g} . / 100 \mathrm{ml} .) \\
\text { Cases } \ldots\end{array}$ & $\cdots$ & $<{ }_{2}^{4 \cdot 2}$ & $\begin{array}{c}4 \cdot 2-5 \cdot 6 \\
8\end{array}$ & $\begin{array}{c}5 \cdot 6-7 \\
11\end{array}$ & $\begin{array}{c}7-8 \cdot 4 \\
18\end{array}$ & $\begin{array}{c}8 \cdot 4-9 \cdot 8 \\
19\end{array}$ & $\begin{array}{c}9 \cdot 8-11 \cdot 2 \\
6\end{array}$ & $11 \cdot \underset{2}{2-12 \cdot 6}$ \\
\hline
\end{tabular}


The following age distribution was found in the present series:

\begin{tabular}{lc|c|c|c|c|c|c|c}
\hline Age (years) & $\ldots$ & $0-1^{*}$ & $1-2$ & $2-3$ & $3-4$ & $4-5$ & $5-6$ & 6 \\
\hline Cases .. & $\ldots$ & 8 & 14 & 23 & 7 & 5 & 3 & 1 \\
\hline Deaths & $\cdots$ & 1 & 4 & - & - & - & - & - \\
\hline
\end{tabular}

* The youngest age recorded was 3 months.

Many cases were very anaemic when admitted and this is borne out by the fact that $65.5 \%$ of the cases were transfused. There was only one fatal case among those transfused. The other four died because there was no blood immediately available, or so soon after admission that transfusion was not feasible.

Sickle Cell Anaemia. Out of 66 cases who ware sicklers, 45 were diagnosed as sickle cell anaemia on the presence of either dactylitis, characteristic radiological bony changes or of $\mathrm{Hb} \mathrm{S}$ only on paper electrophoresis. Tribal distribution showed 54 Ganda, two Ruanda-Urundi and 10 'others'. Fifteen patients $(22 \%)$ were transfused.

The age distribution was as follows:

\begin{tabular}{cc|c|c|c|c|c|c|c}
\hline Age (years) &. & $0-1$ & $1-2$ & $2-3$ & $3-4$ & $4-5$ & $5-6$ & 6 \\
\hline Cases.. &. & 26 & $\begin{array}{r}11 \\
\text { Deaths }\end{array}$ & $\begin{array}{r}10 \\
2\end{array}$ & $\begin{array}{r}6 \\
2\end{array}$ & $\begin{array}{r}8 \\
2\end{array}$ & 3 & 2 \\
\hline
\end{tabular}

Twenty-five cases had dactylitis or periosteal bone reaction. In two cases Salmonella typhimurium was isolated on culture of the lesion. Staphylococcus pyogenes was reported in another two and in one both Staphylococcus albus and alpha haemolytic streptococci were found.

Haemoglobin estimations in this group are given in Table 16.

\begin{tabular}{|c|c|c|c|c|c|c|c|c|}
\hline Age (yrs) & $6 \mathrm{mths}$ & $0.5-1$ & $1-2$ & $2-3$ & $3-4$ & 4-5 & $5-6$ & 6 \\
\hline $\begin{array}{l}\text { Male } \\
\text { Female }\end{array}$ & $\begin{array}{l}31 \\
14\end{array}$ & $\begin{array}{l}23 \\
18\end{array}$ & $\begin{array}{l}35 \\
17\end{array}$ & $\begin{array}{r}17 \\
8\end{array}$ & 3 & 5 & $\begin{array}{l}3 \\
3\end{array}$ & 1 \\
\hline
\end{tabular}

It is found that the highest incidence is in the first two years of life. This is also the time when the diseases, such as measles and whooping cough, attack children. It was apparent that many of the pneumonias admitted were complications of measles and whooping cough.

Acute laryngo-tracheo-bronchitis is a disease which has been diagnosed more frequently in Kampala of recent years and carries a high mortality $(24 \%)$. In addition, out of the 29 cases, tracheotomy was performed in $12(41 \%)$.

\section{(VII) Miscellaneous Group}

Meningitis. There were 60 cases of meningitis in this series, of whom 22 died (37\%). Twenty-two were caused by Haemophilus influenzae (three deaths). There were nine pneumococcal cases with five deaths. In 31 cases of purulent meningitis, in which no organism was isolated, there were 14 deaths. In only one case were meningococci isolated and the patient recovered.

The mortality of $22(37 \%)$ appears high, but must be considered in relation to the fact that many of the patients come in very late and have often been partially and inadequately treated.

Congenital Abnormalities. This group includes congenital abnormalities, for which patients are admitted, and does not give the incidence of minor congenital anomalies in all patients admitted, as they were not specifically looked for or recorded.

There were five cases of congenital heart disease, three of hare lip and cleft palate, three of hydrocephalus, two of spina bifida with meningocele, two

TABLE 16

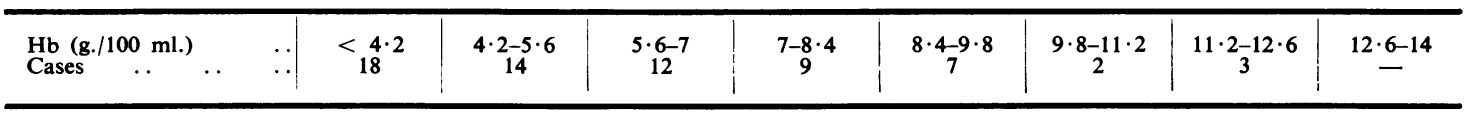

(VI) Respiratory Diseases. Diseases of the respiratory system are commonly seen in the outpatients and in the child welfare clinics. Many of them are not admitted but treated as out-patients and only very seriously ill patients are admitted because of the limited bed space. This gives a high mortality rate.

Pneumonias have been grouped together, and showed the following age distribution: mongols (one with congenital heart disease and the other with congenital cataracts), two with congenital laryngeal stridor and one case of each of the following: sacrococcygeal teratoma, hypertrophic pyloric stenosis, exomphalos, cystic hygroma, posterior urethral valves, congenital dislocation of the hip, imperforate anus, ectopic anus, micrognathia, cranofacial dysostosis and arthrogryposis multiplex congenita. 
Infection of Skin, Bone and Soft Tissues. There was one case of each of the following conditions: vaginitis, peritonitis, pelvic abscess, cellulitis of leg, pyomyositis and abscess of the neck.

There was only one child diagnosed as having eczema and one with chronic ulceration of the skin of unknown aetiology. Ten newborn babies were admitted with umbilical sepsis.

There were three cases of osteomyelitis (excluding those associated with sickle cell anaemia).

Heart Disease. There were four cases of rheumatic heart disease and all recovered from the acute illness; three cases of congestive cardiac failure of unknown aetiology, one of whom recovered, while two died within 24 hours of admission. One child died of purulent pericarditis, confirmed at autopsy.

Poliomyelitis. Four cases of poliomyelitis were admitted to the ward. None were fatal.

Poisoning. There were 15 cases of poisoning. Eleven were due to kerosene poisoning (two deaths) and two cases each from waragi (locally distilled spirits) and probably from mushroom poisoning.

Malignant Tumours. There were five cases of malignant disease in the present series, four were malignant lymphomas and the other was sarcoma of the maxilla. All except one died in hospital.

Renal Disease. There were 18 cases of renal disease, eight acute nephritis and five pyelitis. There were two deaths, one from nephrosis and pneumonia, and the other from congenital cystic kidney, diagnosed clinically as uraemia.

Tetanus. There were 13 cases of tetanus in all age groups with recovery of only two cases. (These figures are biased by the inclusion of 10 cases of tetanus neonatorum, all of whom died.)

Infections. Included in this group are two cases of measles, one of brucellosis, one fatal case of widespread moniliasis of the respiratory and alimentary tracts, and two cases of congenital syphilis, presenting with jaundice and anaemia.

Miscellaneous. Included in this group are five cases of epilepsy, six babies with melaena neonatorum, 10 cases of prematurity, three cases of birth injury and one of the peculiar local form of dwarfism, known as Nakalanga (Raper and Ladkin, 1950).

\section{Discussion}

The high mortality rate and the difficulties briefly touched on in the present paper leave no doubt as to the magnitude of the problem facing the paediatrician in an underdeveloped tropical country. Luder (1957) ably presented the problems when he gave the results of his two years' experiences in
Uganda. There has been no material expansion of the paediatric unit since his time, but there has been a steadily increasing flood of patients, as judged for example, by a six-fold increase in paediatric out-patients in the past six years, and probably also a changing pattern of childhood disease.

In discussing the age incidence of serious disease, it is obvious that the highest morbidity is in children up to 3 years of age. It is the period when children's infections, malnutrition and helminthic infestations are most severe and burdensome. In the tropics, the relationship between malnutrition, infection, poverty and ignorance is so interwoven that it is often difficult to define the exact part contributed by each to the problems of child health.

Certain facts seem to appear as a result of this bird's-eye view of the grosser aspects of paediatric cases seen in Mulago Hospital.

For example, the local aetiology of anaemias still requires further elucidation. There is a group of haemolytic anaemias for which the ordinary haematological investigations do not appear to assist in diagnosis. Inadequate histories always add to the difficulty.

Febrile convulsions are another very common syndrome in young children here. Investigation as to causation, in relation, for example, to cerebral malaria and encephalitis, is much needed.

Obvious neonatal infections are frequent and have a high mortality. The incidence of less obvious syndromes, such as sepsis neonatorum, is unknown.

Poliomyelitis was diagnosed in only four cases admitted to the ward. This is, however, a small figure compared with the continuous trickle of cases seen in the out-patients, who are referred direct to the physiotherapy department. It is clear, in fact, that poliomyelitis is highly endemic in Uganda, and the slowly rising standards of hygiene in some areas can be expected to be followed by actual outbreaks, unless prevented by immunization.

Congenital syphilis is rarely seen either in the out-patients or as a cause for admission. It would, however, come in the differential diagnosis of dactylitis of sickle cell disease, of babies with jaundice or anaemia or failure to thrive. The reason for this apparent rarity is not known, but it seems possible that the widespread use of penicillin, at least in towns, might be relevant.

Probably the most significant trend is that towards a progressively higher incidence of gastroenteritis in young infants. This is mainly associated with a falling off of breast-feeding in the towns, and poses a huge and threatening problem. A rehydration centre at Mulago Hospital is in the process of development. 
Many congenital and genetic diseases (apart from sickle cell anaemia) are at present obscured by the mass of 'environmental' paediatrics. It is impossible to concentrate on less common but interesting maladies which are at present missed as a result of the daily scramble to find a bed for the next admission.

There is a real need to assess the present status of child health in Uganda in greater detail. Community studies in different groups are already being carried out, while in order to be able to reassess the situation in hospital with advantage, better hospital statistics are essential in future, ideally with especially prepared proforma suitable for yearly analysis.

In spite of the many difficulties, work under these adverse conditions is interesting and, provided there is balanced progress between preventive medicine and the curative services many of the paediatric problems of today will be overcome as the majority of the admissions are due to preventable diseases. The main need is for health education, which requires development in all directions, in order to break the vicious circle formed by ignorance, malnutrition, disease and poverty.

Unfortunately, neither the public nor those in politics or administration are aware of the huge, but preventable, problems of child welfare in Uganda, so that the necessary emphasis on child health is developing too slowly, but may perhaps gain impetus in the next few years.

\section{Summary}

The child morbidity and mortality has been studied by the analysis of admission of children to the Paediatric Division, Mulago Hospital, in 1959. The main causes for admission have been discussed. The tribal, age and sex distributions are noted. The high morbidity and mortality in early childhood are noted and some of the tropical paediatric problems contributing to this high death rate are discussed.

I am most grateful to Professor D. B. Jelliffe and Dr. C. E. Stroud for encouragement and help during the preparation of this paper, and to the Chief Medical Officer, Uganda, for permission to publish.

\section{REFERENCES}

Davies, J. N. P. (1954). Second Inter-African Conference on Nutrition. Gambia, 1952, p. 84. H.M. Stationery Office, London.

Greaves, J. L. and Welch, R. G. (1951). Report on the work of the gastroenteritis unit at the hospital for sick children for the year 1950. Gt Ormond Str. J., No. 2, 115.

Jelliffe, D. B. (1959). Protein-calorie malnutrition in tropical preschool children. J. Pediat., 54, 227.

Luder, J. (1956). The diarrhoea and vomiting syndrome in African children in Uganda. J. trop. Pediat., 2, 115.

(1957). Some paediatric problems in Uganda. Brit. med. J., 2, 1143 .

Raper, A. B. and Ladkin, R. G. (1950). Endemic dwarfism in Uganda. E. Afr. Med. J., 27, 339.

Scott, J. A. (1953). Gastro-enteritis in infancy. From The Public Health Dept., L.C.C. Brit. J. prev. Soc. Med., 7, 194.

Welbourn, H. F. (1955). The danger period during weaning. J. trop. Pediat., 1, 34.

- (1958). Bottle-feeding: A problem of modern civilization Ibid., 3, 157.

Wilson, A. and Luder, J. (1957). The bacteriology, microscopy and treatment of diarrhoea in children in Uganda. Ibid., 3, 128. 